\title{
Cell-free synthesis of a functional $G$ protein- coupled receptor complexed with nanometer scale bilayer discs
}

\author{
Jian-Ping Yang, Tatiana Cirico, Federico Katzen, Todd C Peterson and Wieslaw Kudlicki
}

\begin{abstract}
Background: G protein coupled receptors (GPCRs) represent the largest family of membrane proteins in the human genome and the richest source of targets for the pharmaceutical industry. A major limitation to characterizing GPCRs has been the difficulty in developing high-level heterologous expression systems that are cost effective. Reasons for these difficulties include inefficient transport and insertion in the plasma membrane and cytotoxicity. Additionally, GPCR purification requires detergents, which have a negative effect on receptor yields and stability.

Results: Here we report a detergent-free cell-free protein expression-based method to obtain pharmacologically active GPCRs in about 2 hours. Our strategy relies on the co-translational insertion of modified GPCRs into nanometer-sized planar membranes. As a model we employed an engineered $\beta 2$-adrenergic receptor in which the third intracellular loop has been replaced with T4 lysozyme ( $\beta 2 A R-T 4 L)$. We demonstrated that nanolipoprotein particles (NLPs) are necessary for expression of active $\beta 2 A R$-T4L in cell-free systems. The binding specificity of the NLP- $\beta 2$ AR-T4L complex has been determined by competitive assays. Our results demonstrate that $\beta 2 A R-T 4 L$ synthesized in vitro depends on similar oxidative conditions as those required by an in vivo-expressed receptor.

Conclusions: Although the activation of $\beta 2 A R-T 4 L$ requires the insertion of the T4 lysozyme sequence and the yield of that active protein limited, our results conceptually prove that cell-free protein expression could be used as a fast approach to express these valuable and notoriously difficult-to-express proteins.
\end{abstract}

\section{Background}

With over 1000 members, G-protein-coupled receptors represent the largest family of integral membrane proteins, whose corresponding genes span $>1 \%$ of the human genome [1]. Despite their remarkable topological similarity (they all have a seven-transmembrane - $\alpha$-helical topology), they respond to a plethora of extracellular stimuli, mediating cellular responses to hormones, neurotransmitters and senses such as smell, taste, and sight. Their relevance in signal transduction and their extraordinary diversity have turned them into the most pursued drug targets (>60\% of the industry), which generate $\$ 50$ billion in pharmaceutical sales per year [2].

Major limitations to studying GPCRs include the difficulties in using high-level heterologous expression

\footnotetext{
* Correspondence: toni.kudlicki@liftech.com

Life Technologies, 5791 Van Allen Way, Carlsbad, CA 92008, USA
}

platforms (being baculoviral-mediated and transient mammalian expression the most commonly used) and the unpredictability of the expression outcome. It is apparent that the folding mechanism and stability of these molecules in their native systems are quite complex. This notion imposes a key obstacle, as the natural abundance of these proteins is too low to purify sufficient material for functional and structural studies.

Another difficulty is that GPCRs are naturally embedded in a complex and dynamic lipid bilayer, which restricts the use of many standard biophysical techniques used for studying soluble proteins. The use of detergents is often questioned, as it is unclear how well micelle structures mimic the natural membrane protein environment. On the other hand, reconstitution of GPCRs into artificial bilayers is not a trivial process, and results in structures that are too heterodisperse to be used in structural studies.

\section{() Biomed Central}


Another complication in the study of GPCRs is their inherent conformational plasticity. With the exception of rhodopsin, which is locked into an inactive state by its covalently bound inverse agonist 11-cys-retinal, GPCRs adopt different states of activity, which precludes determining their tridimensional structure [3]. Recent breakthroughs have been the resolution of ligand bound inactive-state structures of GPCRs [4-9], where a variety of protein modifications and engineering approaches were applied to stabilize the proteins.

Cell-free protein expression is increasingly being considered as viable alternative for overcoming the above obstacles (for a recent review see [10]). However, all current cell-free approaches used to express functional GPCRs require protein solubilization in detergent micelles or reconstitution into lipid membranes [11-14]. In order to circumvent these obstacles, we have recently proposed a novel cell-free protein expression strategy based on the use of 'nanodiscs' or 'nanolipoprotein particles' (NLPs) [15,16].

NLPs are self-assembled discoidal particles composed of a planar phospholipid membrane bilayer surrounded by an apolipoprotein ring (scaffold protein) [17]. The approach makes use of NLPs, which are either added to or in situ assembled in the cell-free reaction, providing support for the nascent membrane protein and thereby circumventing subsequent protein extraction and reconstitution steps. The main limitation is that wild-type GPCRs expressed under these conditions lack ligand binding activity (unpublished results).

Here we report the cell-free synthesis of functional human adrenergic $\beta 2$ receptor ( $\beta 2 \mathrm{AR}$ ) that has been stabilized through the insertion of the T4 bacteriophage lysozyme ( $\beta 2 \mathrm{AR}-\mathrm{T} 4 \mathrm{~L})$ [5]. We also show that ligand binding activity is attainable without the need of detergent solubilization or membrane reconstitution.

\section{Results}

B2AR-T4L complexes with NLPs and binds a specific antagonist - relevance of the lysozyme insertion

In an effort to produce functional GPCRs in vitro without relying on detergent solubilization or membrane reconstitution, nine members of this receptor family were expressed in the presence of NLPs [15]. Unfortunately, none of them, albeit associated with NLPs, exhibited ligand binding activity (results not shown). After numerous unsuccessful attempts that involved the reworking of the expression conditions, the addition of folding catalysts, and the use of a variety of $\mathrm{N}$ - and $\mathrm{C}$ terminal fusion partners, we focused our attention on a recently reported stabilized variant of $\beta 2 \mathrm{AR}[5,6]$. The molecule harbors a T4 lysozyme insertion within the third intracellular loop, which does not impair critical biochemical consequences on the receptor other than slightly elevated agonist binding affinities $[5,6]$. When this protein was expressed in our cell-free protein expression system in the presence of NLPs, specific and displaceable binding to the antagonist $\left[{ }^{3} \mathrm{H}\right]$-dihydroalprenolol ([ $\left.\left.{ }^{3} \mathrm{H}\right] \mathrm{DHA}\right)$ was observed (Figure $1 \mathrm{~A}$ and $1 \mathrm{~B}$ ). In contrast, $\beta 2 \mathrm{AR}$ failed to exhibit binding even though identical reaction conditions were applied (Figure 1A and $1 \mathrm{~B})$. Additional experiments showed that other nonspecific ligands failed to bind the NLP- $\beta 2 A R-T 4 L$ complex (not shown). The receptor variants ( $\beta 2 \mathrm{AR}-\mathrm{T} 4 \mathrm{~L}$ and $\beta 2 \mathrm{AR}$ ) expressed at similar levels (Figure $1 \mathrm{C}$ ), and complexed with the NLPs in a similar fashion, generating a supramolecular complex of an apparent weight of about $250 \mathrm{kDa}$ (Figure 1D). However, only $\beta 2 \mathrm{AR}-\mathrm{T} 4 \mathrm{~L}$ was able to bind $\left[{ }^{3} \mathrm{H}\right] \mathrm{DHA}$ (Figure $1 \mathrm{~A}$ ). Previous reports indicated that cholesterol was relevant in the stability and function of $\beta 2 \mathrm{AR}[18,19]$. However, in our conditions, the addition of cholesterol to the reaction did not result in significant changes in the activity of in vitro expressed $\beta 2 A R$ or $\beta 2 A R-T 4 L$ (not shown). Taken together, these results suggest that the insertion of the T4 lysozyme moiety (major difference between the two receptor variants) may play a crucial role assisting the molecule to attain a functional and/or more stable conformation in preformed NLPs.

\section{Pharmacological characterization of cell-free expressed B2AR-T4L}

In order to assess whether $\beta 2 \mathrm{AR}-\mathrm{T} 4 \mathrm{~L}$ was properly folded, we determined its ligand binding constants. Our approach combines cell-free protein expression and ligand binding in a single reaction. The radioligand is added at time zero, and binding takes place as proteins are translated and complexed with the NLPs. Protein concentration and folding is driven by the amount of programming DNA and reaction conditions. Therefore, higher variability than in conventional ligand binding assays is expected. Saturable affinity binding curves were obtained using $\left[{ }^{3} \mathrm{H}\right] \mathrm{DHA}$ as the radioligand, and propranolol as the unlabelled competitor. Results showed that the dissociation constant $(\mathrm{Kd})$ of the cell-free product (Figure 2A) was close to what is observed with $\beta 2 \mathrm{AR}$ T4L expressed and purified from insect cells (Figure $2 \mathrm{~B})$, However, the estimated maximal number of receptor binding sites (Bmax) for the cell-free made protein was significantly lower than that one produced in insect cells (compare Figure 2A with 2B). These findings, as will be discussed below, suggest that only a small fraction of the total protein produced attained its proper active conformation.

One way to estimate the amount of active receptor produced stems from the calculated Bmax parameter (9 fmol DHA/ $\mu$ g receptor). Assuming one binding site per molecule $(\mathrm{MW}=56941 \mathrm{Da})$, and knowing that the 


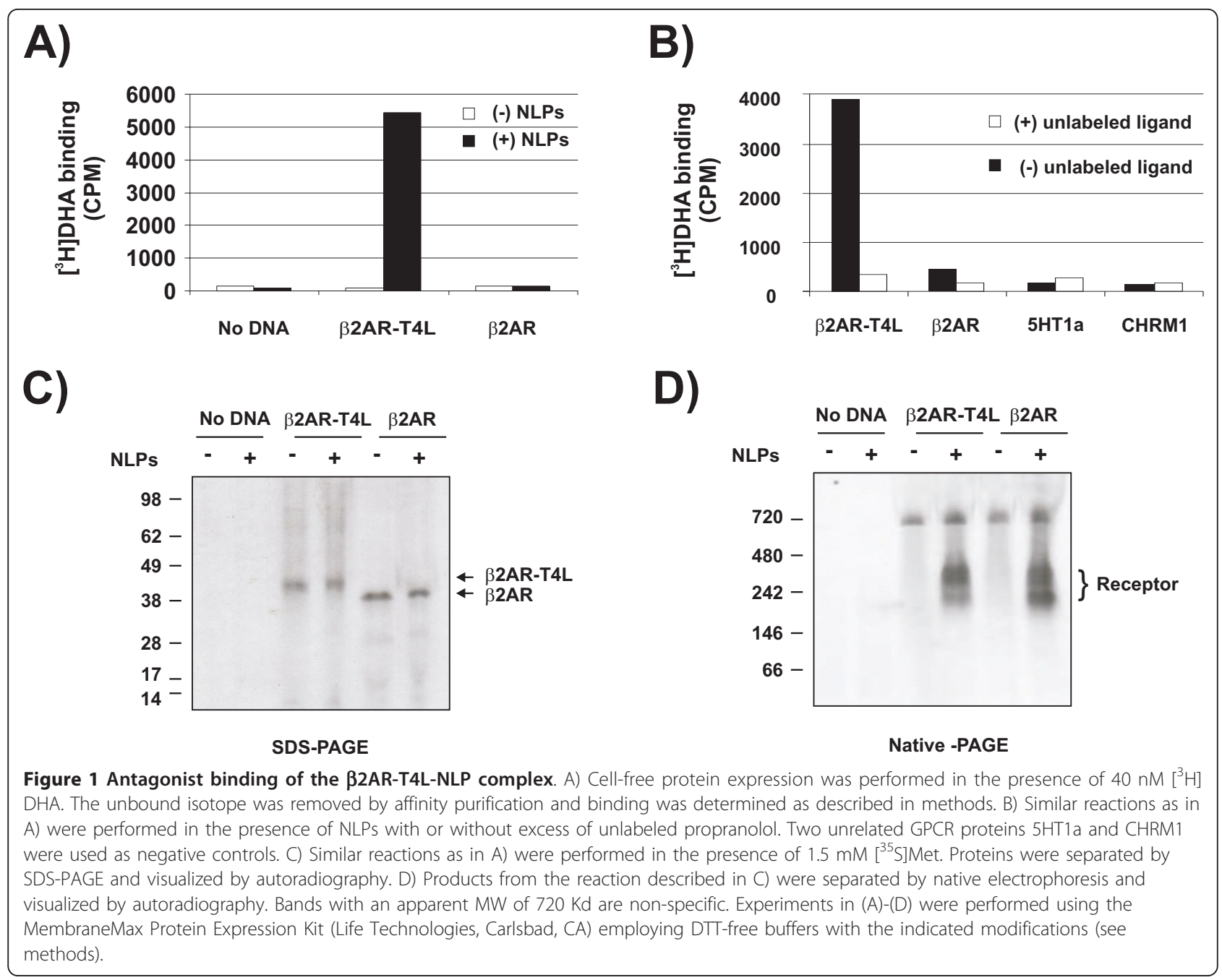

overall GPCR yield (according to $\left[{ }^{35} \mathrm{~S}\right]$ Met trace labeling) was $100 \mu \mathrm{g} / \mathrm{ml}, 51 \mathrm{ng}$ of $\mathrm{GPCR} / \mathrm{ml}$ of reaction was obtained. A second approach to estimate that value is through the equation "Bmax cell-free expressed receptor/Bmax insect cell-expressed receptor $\times$ yield cell-free expressed receptor", assuming the insect-cells expressed protein is fully functional. Applying the latter formula the total amount of active receptor per $\mathrm{ml}$ of reaction should be $65 \mathrm{ng} / \mathrm{ml}$, very close to the number above. Differences inherent to the expression platform used (insect cells vs. prokaryote cell-free) such as post-translational modifications, membrane composition, and sample processing may also account for this discrepancy.

To further characterize the cell-free expressed receptor, affinity competition experiments were carried out. The natural antagonist epinephrine and the high-affinity synthetic agonist formoterol were used (Figure 3). The relative affinities for these ligands was similar as that one observed using membranes isolated from insect cells expressing $\beta 2 \mathrm{AR}-\mathrm{T} 4 \mathrm{~L}$ [5].
Taken together, the results above suggest the protein synthesized in vitro exhibit similar pharmacological properties as those described earlier [5]. These findings validate the cell-free protein expression approach as a viable vehicle to obtain functional $\beta 2 \mathrm{AR}-\mathrm{T} 4 \mathrm{~L}$, albeit with limited folding capacity.

\section{Oxidative protein folding is required for ligand binding}

Early reports showed that two extracellular disulfide bonds in the wild type $\beta 2 A R$ are required for ligand binding $[20,21]$. More recently, it was shown that the ligand accessibility in $\beta 2 \mathrm{AR}-\mathrm{T} 4 \mathrm{~L}$ is enabled by these pairs of closely spaced disulfide bridges [6]. To verify that the activity of the in vitro expressed $\beta 2 \mathrm{AR}-\mathrm{T} 4 \mathrm{~L}$ still relies on disulfide bond formation, we expressed this protein using cell-free expression systems with different reducing strengths. The results showed that increasing reducing potential is detrimental to the ligand binding capacity of $\beta 2 A R-T 4 L$ (Figure 4A). In addition derivatives of this protein where two of the essential cysteines were replaced by serine residues 


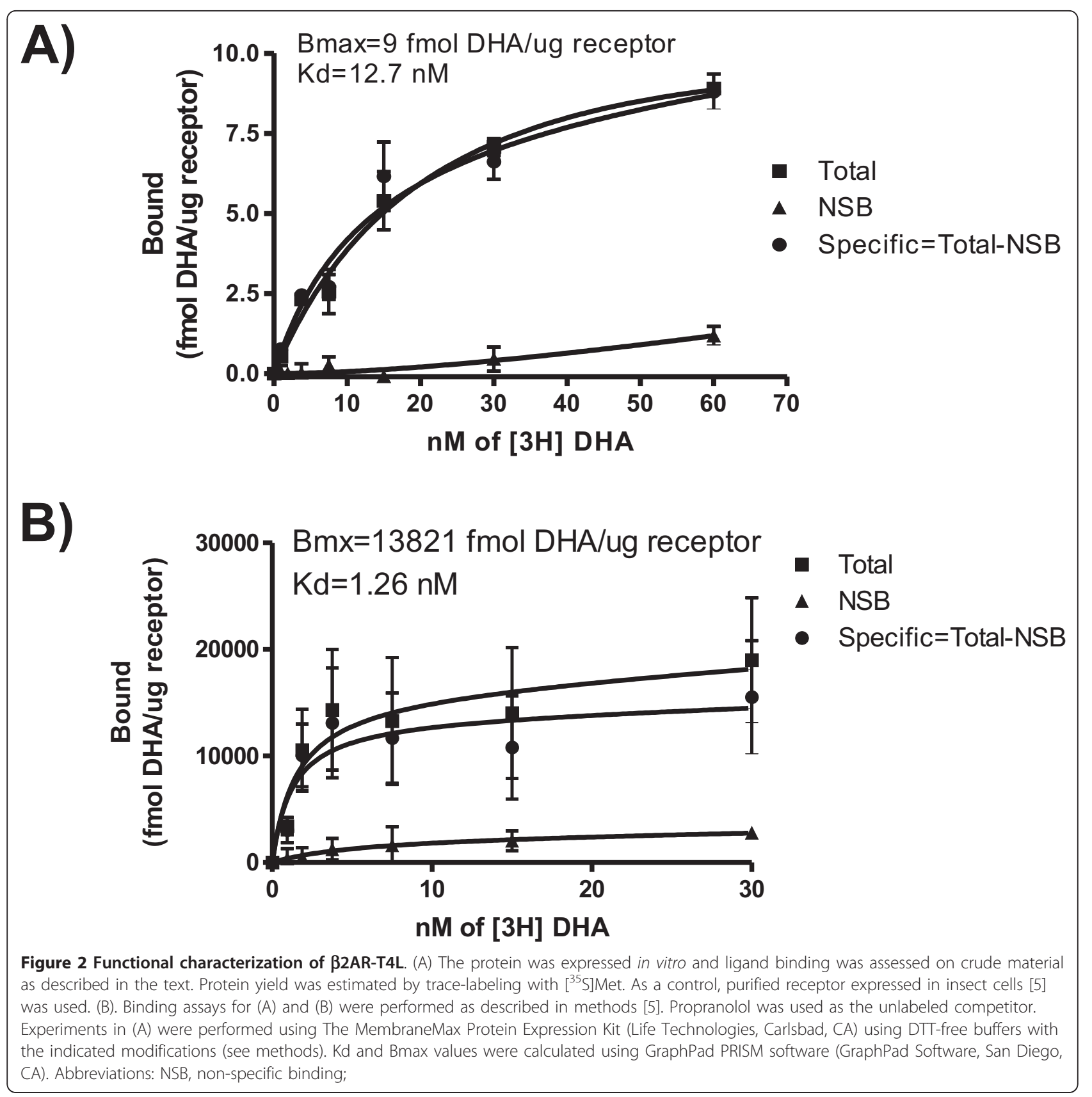

produced receptors with significantly lower specific binding activity (Figure 4B).

In summary, our results demonstrate that $\beta 2 \mathrm{AR}-\mathrm{T} 4 \mathrm{~L}$ synthesized in vitro, depends on similar oxidative conditions as those required by an in vivo expressed protein.

\section{Discussion}

The primary objective of our work was to find a practical solution to the limitations of GPCR expression imposed by heterologous systems. Although relatively large amounts of membrane proteins can be potentially produced in cellular systems, usually a small proportion becomes associated to the membrane [22]. Particularly, GPCRs are confronted to a complex array of trafficking signals, post-translational modifications, and transport systems before reaching the final destination, the plasma membrane. In addition, differences in the lipid bilayer composition and maximal tolerated membrane protein loads can additionally affect the correct insertion, folding, and yield of recombinant GPCRs.

In order to overcome these difficulties, we developed a cell-free expression system supplemented with planar 


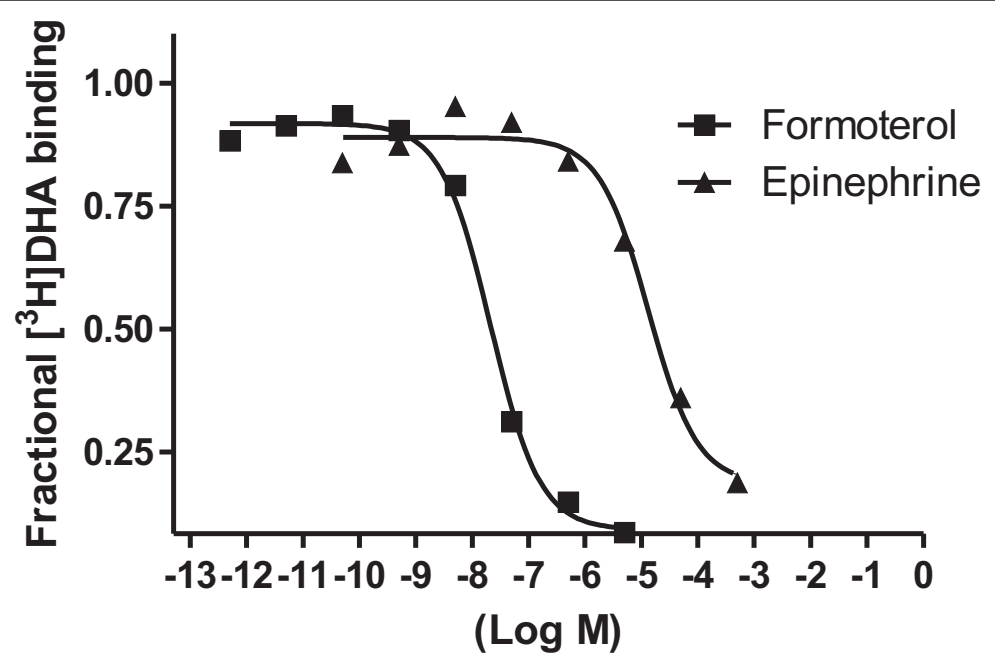

Figure 3 Affinity competition curves for adrenergic ligands. Binding experiments were performed on crude material from cell-free reactions as described in methods using $\left[{ }^{3} \mathrm{H}\right] \mathrm{DHA}$ and the indicated unlabelled competitors.

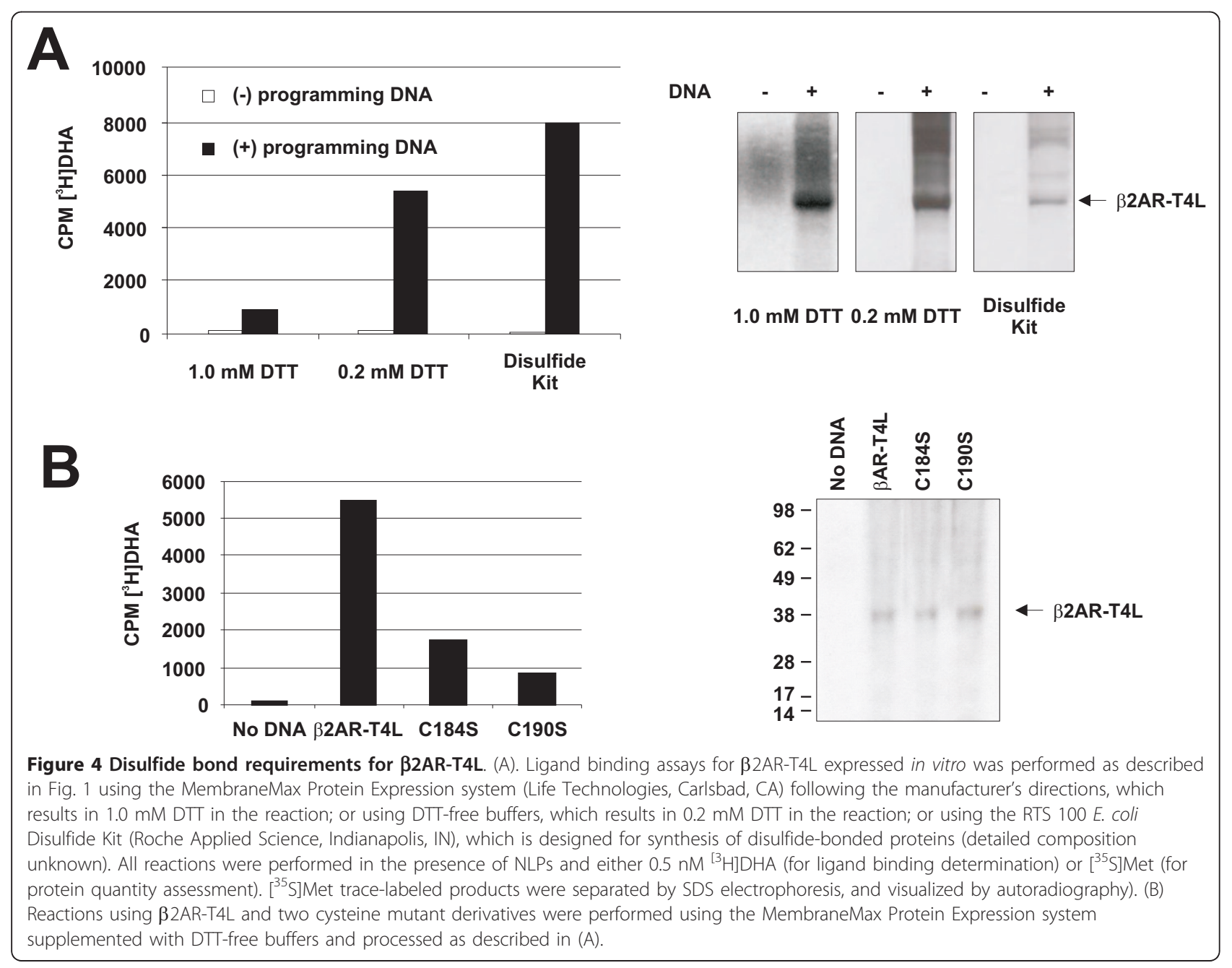


membranes [15]. Although, the approach excels in expressing soluble membrane protein products, it fails to produce functional GPCRs. We favor the absence of a functional translocon machinery embedded in the membrane particles as one of the major reasons for this negative outcome.

We reasoned that a way to overcome this deficiency would be to employ GPCR derivatives that insert into the membrane in a translocase-independent fashion (for a recent review on membrane protein insertion see [23]). Since there is no in silico approach to establish $a$ priori the type membrane insertion mechanism of a given protein, our strategy was to try active variants reported in the literature. Our attempt was to employ one of the stable $\beta 2 \mathrm{AR}$ derivatives recently described, where the third intracellular loop was replaced by $\mathrm{T} 4$ lysozyme [6].

The strategy proved to work. The enzyme complexed with the NLPs and exhibited similar affinity properties as those ones reported in vivo [5]. Perhaps the clearest advantage of this method is its short processing time: it only takes about 2 hours to go from gene to ligand binding assay.

Although the cell-free made enzyme showed a similar dissociation constant as that one made in-vivo, the maximal number of ligand sites appeared to be significantly lower. Namely, only a fraction of the receptors seems to be active. These findings suggest that additional components such as folding catalysts, specific lipid constituents, post-translational modifications, or a membrane protein insertion machinery, absent in our reaction conditions, may be required by $\beta 2 \mathrm{AR}-\mathrm{T} 4 \mathrm{~L}$ to attain a high specific activity. Conversely, elimination of some proteases present in the cell-free extract may contribute to provide a better context for more stable GPCRs. While this observation does not affect the benefit of this approach as a rapid screening method for analyzing GPCR activity, further experimentation is needed to establish the nature of the deficiency. For example, the generation of cholesterol-containing NLPs, or the use of NLPs bearing the SEC translocon would likely shed light on this subject (for reconstitution of the SecYEG complex into NLPs see [24]).

The replacement of the third intracellular loop by T4 lysozyme as a strategy to stabilize GPCR molecules has been proven successful for other GPCR molecules [9]. In addition, other GPCR stabilization approaches have demonstrated success (see for example [8]). Finally, the incorporation of unnatural amino acids into crucial regions of these elusive molecules holds the promise of overcoming some of these difficulties [25].The assay of these other variants in our cell-free approach will help determine what aspects of the GPCR biochemistry are critical for reaching its proper conformation.

\section{Conclusion}

Our results conceptually prove that cell-free protein expression could be used as a fast approach to express these valuable and notoriously difficult-to-express proteins. To our knowledge, this was the first time that a functional GPCR was obtained in a cell-free context, with no further re-folding or reconstitution requirements. The modified cell-free system combined with NLP offers the unique opportunity to produce sufficient expression levels of soluble and functional folded GPCR for pharmacological assays that are difficult to obtain with other expression systems. Finally, the use of NLPs with different chemistries should allow fine-tuning of the conditions optimal for expression and solubilization of specific MPs in near-native context.

\section{Methods}

\section{Plasmids and clones}

The wild type version of the human adrenergic $\beta 2$ receptor ( $\beta 2 A R$, GenBank acc\# NM_000024), human serotonin receptor 1a (5HT1a, GenBank acc\# NM_000524), human muscarinic 1 receptor (CHRM1, GenBank acc\# NM_000738), were retrieved from the Ultimate ORF collection (Life Technologies, Carlsbad, CA), PCR-amplified, and cloned into the plasmid pEXP5-NT/TOPO (Life Technologies, Carlsbad, CA). Details of the construct that expresses $\beta 2 A R-T 4 L$ were published elsewhere [5]. Site directed mutagenesis of the cysteine residues was performed utilizing the GENEART site directed mutagenesis kit (Life Technologies, Carlsbad, CA) employing the following oligonucleotide pairs: 5'-CATCAGGAAGCGATCAACTCCTATGCGGAAGAAAC-3' and 5'-GTTTCTTCCGCATAGGAGTTGA TCGCTTCCTGATG-3' (for cysteine 184), and 5'-GG AAGAAACTTCCTGCGACTTTTTCACCAACCAG GCG-3' and 5-CGCCTGGTTGGTGAAAAAGTCGC AGGAAGTTTCTTCC-3' (for cysteine 190).

\section{Cell-Free Protein Expression Reactions}

Cell-free protein expression was conducted using the MembraneMax ${ }^{\mathrm{TM}}$ Protein Expression Kit (Life Technologies, Carlsbad, CA) either following the manufacturer's direction or replacing the buffers with similar ones devoid of DTT. Where indicated the RTS 100 E. coli Disulfide Kit (Roche Applied Science, Indianapolis, IN) was used in a batch configuration supplementing the reactions with NLPs as indicated previously [15]. Where indicated, reactions were supplemented with $\left[{ }^{35} \mathrm{~S}\right] \mathrm{Met}(135 \mathrm{mCi} / \mathrm{mmol}$ final) (Perkin Elmer, Waltham, MA) or varying amounts of $\left[{ }^{3} \mathrm{H}\right]$ DHA (Perkin Elmer, Walthman, MA) as indicated.

\section{Protein yield and ligand binding determination assays}

Yield in cell-free protein expression reactions was determined by $\left[{ }^{35} \mathrm{~S}\right]$ Met trace labeling. Reaction products 
were separated by SDS-PAGE or by native electrophoresis using NativePAGETM Novex ${ }^{\circledR} 4-16 \%$ Bis-Tris Gels (Life Technologies, Carlsbad, CA) and visualized by autoradiography.

Binding assays were performed in the presence of $\left[{ }^{3} \mathrm{H}\right]$ DHA added directly to the cell free protein expression reactions. Non-specific binding was assessed by performing identical reactions in the presence of $1 \mu \mathrm{M}$ propranolol (Sigma-Aldrich, Saint Louis, MO) as indicated. Unbound isotopes, $\left[{ }^{35} \mathrm{~S}\right]$ Met and $\left[{ }^{3} \mathrm{H}\right] \mathrm{DHA}$, were removed by purifying the protein products through $\mathrm{Ni}^{+2}$ affinity beads (Life Technologies, Carlsbad, CA) via a histidine tag fused to the receptor molecule. Briefly, the binding assay was performed on a 96-well GF/C filter plate (Perkin Elmer, Walthman, MA), pre-treated with $0.3 \%$ polyethylenimine (PEI), and washed four times with $500 \mu \mathrm{l}$ of ice cold binding buffer $(50 \mathrm{mM}$ Tris- $\mathrm{HCl}$, $\mathrm{pH7.4}, 150 \mathrm{mM} \mathrm{NaCl}, 5 \mathrm{mM}$ imidazole). Then $100 \mu \mathrm{l}$ of nickel resin beads were added and washed 5 times with $150 \mu \mathrm{l}$ of binding buffer. Beads were then suspended in $55 \mu \mathrm{l}$ of binding buffer and mixed with $45 \mu \mathrm{l}$ of cell-free reaction samples for $20 \mathrm{~min}$ at $\mathrm{RT}$. The binding reaction was stopped by washing 5 times with $150 \mu$ lof binding buffer. After air-drying, the filters were introduced into scintillation vials, mixed with $3 \mathrm{ml}$ scintillation liquid and measured for bound $\left[{ }^{3} \mathrm{H}\right]$ DHA with a Beckman LS5000 scintillation counter. The binding assay for insect protein samples was conducted as described [5]. Competition binding reactions were carried out in the presence of $0.5 \mathrm{nM}\left[{ }^{3} \mathrm{H}\right]$ DHA plus increasing concentrations of unlabelled formoterol (MP Biomedicals, Solon, $\mathrm{OH}$ ), or epinephrine (USP, Rockville, MD) and processed as described above. Raw data was processed and analyzed using software package GraphPad Prism (GraphPad Software, San Diego, CA).

\section{Abbreviations \\ GPCR: G-protein-coupled receptor; NLP: Nanolipoprotein particle; $\beta_{2}$ AR: adrenergic $\beta_{2}$ receptor; 5HT1a: serotonin receptor 1a; CHRM1: muscarinic 1 receptor; DHA: dihydroalprenolol; DTT: dithiothreitol.}

\section{Acknowledgements}

We thank Cromwell Cornillez-Ty and Ray C. Stevens for providing the clone expressing $\beta 2 \mathrm{AR}-\mathrm{T} 4 \mathrm{~L}$ and for fruitful discussions.

\footnotetext{
Authors' contributions

JPY, FK, and TK conceived the work. JPY performed most of the experiments and wrote the manuscript draft. TC performed some of the ligand binding assays. FK wrote the manuscript and helped to analyze the data. TP and WK supervised the whole work. All authors read and approved the final manuscript.
}

\section{Competing interests}

The authors declare that they have no competing interests.

Received: 20 December 2010 Accepted: 23 May 2011

Published: 23 May 2011
References

1. Perez DM: The evolutionarily triumphant G-protein-coupled receptor. Mol Pharmacol 2003, 63(6):1202-1205.

2. McCusker EC, Bane SE, O'Malley MA, Robinson AS: Heterologous GPCR expression: a bottleneck to obtaining crystal structures. Biotechnol Prog 2007, 23(3):540-547.

3. Ranganathan R: Biochemistry. Signaling across the cell membrane. Science 2007, 318(5854):1253-1254.

4. Rasmussen SG, Choi HJ, Rosenbaum DM, Kobilka TS, Thian FS, Edwards PC, Burghammer M, Ratnala VR, Sanishvili R, Fischetti RF, Schertler GF, Weis WI, Kobilka BK: Crystal structure of the human beta2 adrenergic G-proteincoupled receptor. Nature 2007, 450(7168):383-387.

5. Rosenbaum DM, Cherezov V, Hanson MA, Rasmussen SG, Thian FS, Kobilka TS, Choi HJ, Yao XJ, Weis WI, Stevens RC, Kobika BK: GPCR engineering yields high-resolution structural insights into beta2adrenergic receptor function. Science 2007, 318(5854):1266-1273.

6. Cherezov V, Rosenbaum DM, Hanson MA, Rasmussen SG, Thian FS, Kobilka TS, Choi HJ, Kuhn P, Weis WI, Kobilka BK, Steven RC: Highresolution crystal structure of an engineered human beta2-adrenergic $\mathrm{G}$ protein-coupled receptor. Science 2007, 318(5854):1258-1265.

7. Hanson MA, Cherezov V, Griffith MT, Roth CB, Jaakola VP, Chien EY, Velasquez J, Kuhn P, Stevens RC: A specific cholesterol binding site is established by the $2.8 \mathrm{~A}$ structure of the human beta2-adrenergic receptor. Structure 2008, 16(6):897-905.

8. Warne T, Serrano-Vega MJ, Baker JG, Moukhametzianov R, Edwards PC, Henderson R, Leslie AG, Tate CG, Schertler GF: Structure of a beta1adrenergic G-protein-coupled receptor. Nature 2008, 454(7203):486-491.

9. Jaakola VP, Griffith MT, Hanson MA, Cherezov V, Chien EY, Lane JR, ljzerman AP, Stevens RC: The 2.6 angstrom crystal structure of a human A2A adenosine receptor bound to an antagonist. Science 2008, 322(5905):1211-1217

10. Katzen F, Peterson TC, Kudlicki W: Membrane protein expression: no cells required. Trends Biotechnol 2009, 27(8):455-460.

11. Klammt C, Schwarz D, Eifler N, Engel A, Piehler J, Haase W, Hahn S, Dotsch V, Bernhard F: Cell-free production of $G$ protein-coupled receptors for functional and structural studies. J Struct Biol 2007, 158(3):482-493.

12. Klammt C, Srivastava A, Eifler N, Junge F, Beyermann M, Schwarz D, Michel $H$, Doetsch V, Bernhard F: Functional analysis of cell-free-produced human endothelin $B$ receptor reveals transmembrane segment 1 as an essential area for ET-1 binding and homodimer formation. Febs J 2007, 274(13):3257-3269.

13. Ishihara G, Goto M, Saeki M, Ito K, Hori T, Kigawa T, Shirouzu M, Yokoyama S: Expression of $\mathrm{G}$ protein coupled receptors in a cell-free translational system using detergents and thioredoxin-fusion vectors. Protein Expr Purif 2005, 41(1):27-37.

14. Kamonchanok S, Balog Cl, van der Does AM, Booth R, de Grip WJ, Deelder AM, Bakker RA, Leurs R, Hensbergen PJ: GPCR proteomics: mass spectrometric and functional analysis of histamine $\mathrm{H} 1$ receptor after baculovirus-driven and in vitro cell free expression. J Proteome Res 2008, 7(2):621-629.

15. Katzen F, Fletcher JE, Yang JP, Kang D, Peterson TC, Cappuccio JA, Blanchette CD, Sulchek T, Chromy BA, Hoeprich PD, Coleman MA Kudlicki WA: Insertion of membrane proteins into discoidal membranes using a cell-free protein expression approach. J Proteome Res 2008, 7(8):3535-3542.

16. Cappuccio JA, Blanchette CD, Sulchek TA, Arroyo ES, Kralj JM, Hinz AK, Kuhn EA, Chromy BA, Segelke BW, Rothschild KJ, Fletcher JE, Katzen F, Peterson TC, Kudlicki WA, Bench G, Hoeprich PD, Coleman MA: Cell-free co-expression of functional membrane proteins and apolipoprotein, forming soluble nanolipoprotein particles. Mol Cell Proteomics 2008, 7(11):2246-2253.

17. Bayburt TH, Grinkova YV, Sligar SG: Self-assembly of discoidal phospholipid bilayer nanoparticles with membrane scaffold proteins. Nano Lett 2002, 2(8):853-856.

18. Xiang Y, Rybin VO, Steinberg SF, Kobilka B: Caveolar localization dictates physiologic signaling of beta 2-adrenoceptors in neonatal cardiac myocytes. J Biol Chem 2002, 277(37):34280-34286.

19. Yao Z, Kobilka B: Using synthetic lipids to stabilize purified beta2 adrenoceptor in detergent micelles. Anal Biochem 2005, 343(2):344-346.

20. Noda K, Saad Y, Graham RM, Karnik SS: The high affinity state of the beta 2-adrenergic receptor requires unique interaction between conserved 
and non-conserved extracellular loop cysteines. J Biol Chem 1994, 269(9):6743-6752.

21. Dohlman HG, Caron MG, DeBlasi A, Frielle T, Lefkowitz RJ: Role of extracellular disulfide-bonded cysteines in the ligand binding function of the beta 2-adrenergic receptor. Biochemistry 1990, 29(9):2335-2342.

22. Tate CG: Overexpression of mammalian integral membrane proteins for structural studies. FEBS Lett 2001, 504(3):94-98.

23. Xie K, Dalbey RE: Inserting proteins into the bacterial cytoplasmic membrane using the Sec and YidC translocases. Nat Rev Microbiol 2008, 6(3):234-244

24. Alami M, Dalal K, Lelj-Garolla B, Sligar SG, Duong F: Nanodiscs unravel the interaction between the SecYEG channel and its cytosolic partner SecA. Embo J 2007, 26(8):1995-2004.

25. Umanah G, Huang LY, Schultz PG, Naider F, Becker JM: Incorporation of the unnatural amino acid p-benzoyl-L-phenylalanine (Bpa) into a $\mathrm{G}$ protein-coupled receptor in its native context. Adv Exp Med Biol 2009, 611:333-335.

doi:10.1186/1472-6750-11-57

Cite this article as: Yang et al: Cell-free synthesis of a functional G protein-coupled receptor complexed with nanometer scale bilayer discs. BMC Biotechnology 2011 11:57.

\section{Submit your next manuscript to BioMed Central} and take full advantage of:

- Convenient online submission

- Thorough peer review

- No space constraints or color figure charges

- Immediate publication on acceptance

- Inclusion in PubMed, CAS, Scopus and Google Scholar

- Research which is freely available for redistribution

Submit your manuscript at www.biomedcentral.com/submit 